James L. Hanson, Gregory M. Stone and Nazli Yesiller. (2012) Use of Post-Consumer Corrugated Fiberboard as Fine Aggregate Replacement in Controlled Low-Strength Materials. Testing and Specification of Recycled Materials for Sustainable Geotechnical Construction, 9:2, 562-579.

\title{
Use of Post-Consumer Corrugated Fiberboard as Fine Aggregate Replacement in Controlled Low-Strength Materials
}

James L. Hanson, Gregory M. Stone, and Nazli Yesiller

ABSTRACT: This study was conducted to investigate the use of post-consumer corrugated board in controlled low-strength material (CLSM) applications. Corrugated fiberboard (termed corrugate), which constitutes a significant fraction of the municipal solid waste stream in the United States (approximately one third by weight), was used as a partial replacement for fine aggregate in CLSM at aggregate replacement ratios ranging from $0 \%$ (i.e., control) to $6 \%$. The corrugate was fiberized (i.e., repulped) in a blender prior to being mixed with other constituents in the CLSM. The density, air content, and flow consistency of the fresh CLSM were determined, and bleeding was qualitatively assessed. Also, the unconfined compressive strength was determined for the resulting mixtures at different test ages. As the corrugate content increased, air content and water demand increased, density and compressive strength decreased, and some mixtures exhibited excessive bleeding. Corrugated fiberboard was determined to be effective as a fine aggregate replacement to produce mixtures with 28-day compressive strengths within the range for excavatable CLSM. 


\section{Introduction and Background}

Controlled low-strength material (CLSM) is a self-leveling, self-compacting cementitious material used primarily in lieu of compacted sand/soil backfill. Alternative terms for CLSM include flowable fill, unshrinkable fill, controlled density fill, flowable mortar, and soil-cement slurry, among others [1]. ACI Committee Report 116 [2] defines CLSM as a cementitious material that is fluid at placement and which results in a long-term compressive strength of $8.3 \mathrm{MPa}$ (1200 psi) or less. Applications for CLSM include structural fills beneath buildings, backfill behind retaining walls, pavement base, conduit bedding, void filling, and bridge reclamation [1].

Materials used in conventional CLSM mixtures are described in Table 1. Various alternative materials have been used to produce satisfactory CLSM, including high fines (greater than $20 \%$ ), silty sands, and local soils. Soils with high clay contents are avoided, as they can have deleterious effects on mixture properties, such as increased water demand, increased shrinkage, and mixture heterogeneity from incomplete mixing of the clay. [Table 1]

CLSM mixtures must have the ability to fill desired spaces and voids with a minimum need for manual labor during the placement effort. The properties of both fresh and hardened CLSM, including bleeding and density (fresh) and unconfined compressive strength (hardened), provide an indication of the field performance. The engineering properties of CLSM that have relevance to mixture proportioning and performance include flowability, bleeding, density, and unconfined compressive strength as described below.

Flowability refers to the ability of a CLSM to self-compact and readily fill voids. Good flowability as determined using a flow consistency test (ASTM D6103 [10]) allows 
for placement of the CLSM without the need for conventional compaction equipment or labor.

The bleeding of water from a fresh CLSM mixture indicates settlement of the freshly placed CLSM, and typically low bleeding is desirable. The volume of CLSM placed for a given application may need to be increased to account for this settlement and to obtain a desired final surface elevation.

The density of CLSM is affected by mixture materials and amounts. Low density CLSM mixtures are used when low overburden stresses are required (e.g., weak underlying soils or insulating fill for thermal or shock isolation), whereas high density mixtures may be acceptable for cases with relatively high strength requirements.

Unconfined compressive strength is the most commonly used requirement for CLSM mixtures. Several factors influence the requirements for compressive strength, including the application and the likelihood of future excavation. For a given project, a minimum strength, maximum strength, or both may be specified.

The requirements and specifications used for CLSM mixtures are relatively limited compared to those for conventional concrete mixtures. Typical specifications for CLSM include provisions for the proportioning of ingredients (e.g., limits on grain size distributions and mixture proportions), plastic properties (e.g., flowability, segregation), and in-service properties (e.g., compressive strength of the mixture) [1]. Riggs and Keck [11] conducted a survey of CLSM specifications used by six state transportation agencies. For the states surveyed, the only mechanical property specified was the unconfined compressive strength. Several of the states surveyed waived any gradation requirements for aggregates. Some applications for CLSM require unconfined compressive strengths of less than $2.1 \mathrm{MPa}$ 
(300 psi) to allow for future excavation [1]. Limited requirements given in specifications for CLSM mixtures allow for ease of incorporation of byproducts in CLSM mixtures [e.g., Ref 1].

Broad initiatives have been underway since the 1980s to divert materials from landfills by recovering materials for alternative use in CLSM (e.g., Ref 12). When materials are diverted from landfills to construction activities, the costs of both disposal and virgin material are avoided. Many engineering applications have been at the forefront of such reuse due to the high volumetric quantities involved in construction. For such operations, even small replacement ratios translate into significant diversion quantities. CLSM mixtures provide a viable application for incorporating post-consumer byproducts in construction because the performance requirements for CLSM could be less rigorous compared to those for the use of such materials in other cement-based materials such as concrete. Byproducts previously used in CLSM include shredded rubber tires, crushed glass, spent foundry sands, coal combustion products, pulp and paper mill residuals, incinerated sewage sludge ash, and similar materials [12-22].

Byproducts have been used to replace both cementitious materials (e.g., coal combustion byproducts) and aggregates (e.g., recycled glass, foundry cupola-slag, recycled concrete, and scrap tire rubber) in CLSM mixtures. A summary of byproduct materials incorporated in CLSM is presented in Table 2. Several of the byproducts included in mixtures have been materials with relatively high organic or carbon contents (e.g., high carbon content ash, pulp, and paper mill residuals). 
The addition of byproduct materials may require the adjustment of mixture proportions due to changes in the specific gravity and other properties of the byproducts. Poor mixture proportioning of CLSM can lead to excessive bleeding [14,18,19] and fluidity issues [15].

This investigation was conducted to evaluate the innovative use of corrugated fiberboard (referred to as corrugate) as an aggregate replacement for CLSM mixtures. Paper and paperboard constitute the highest fraction by weight and volume of municipal solid waste generated (33\% by weight) and disposed in landfills ( $22 \%$ by weight) in the United States [23]. In 2007, the total amount of paper and paperboard generated in the United States was 83 x $10^{6}$ tons, and the amount disposed of was $37.8 \times 10^{6}$ tons [23]. Due to its high strength to weight ratio, corrugated packaging is poised to be the leading choice for transport packaging in the United States [24]. Approximately $80 \%$ of the paper-based packaging used is corrugated fiberboard shipping containers [24]. Corrugated fiberboard, which is widely used in the manufacturing of corrugated boxes and shipping containers, is a paper-based material consisting of a fluted containerboard sheet and at least one flat linerboard sheet. The use of recovered paper in the manufacturing of containerboard has remained nearly stable (at approximately $16 \times 10^{6}$ tons) since 1997 [25]. Therefore, a practical limit for incorporating waste paper into containerboard has been reached according to the paper industry. The beneficial reuse of corrugated fiberboard in geotechnical engineering and construction applications is not common [26]. Innovative reuse applications (beyond the packaging industry) need to be investigated in order to promote the beneficial reuse of paper products. [Table 2] 
Experimental Test Program

Materials, Mixture Proportions, and Mixing Procedures

The CLSM mixtures were prepared using cementitious materials (cement or cement and fly ash), fine aggregate, water, and fiberized (i.e., repulped) corrugate. Details of the materials used in the test program are provided in Tables 3 and 4 . The baseline mixture design was based on a sample mixture design provided by the Ohio Department of Transportation [1]. The cementitious materials content was identical to those of the sample mixture design, and the fine aggregate content was adjusted to account for differences in the specific gravity of aggregates [American Concrete Institute (ACI) versus local source]. An assumed air content of $3 \%$ was used for batch calculations [36]. Mixtures with variable cement to cementitious materials $(\mathrm{c} / \mathrm{cm})$ ratios were prepared for the test program. The mixtures had c/cm ratios of 0.29 (baseline), 0.65, and 1.0 (entirely portland cement with no fly ash). Fine aggregate was replaced with fiberized corrugate at specified replacement rates (ranging between $0.25 \%$ and $6 \%$ on a dry weight basis). A photograph of a sample of fiberized corrugate (i.e., pulp) is presented in Fig. 1, together with a microscopic image indicating the typical aspect ratios of individual fibers. The corrugated fiberboard was characterized according to Technical Association of the Pulp and Paper Industry (TAPPI) standards (Table 4). Results of the tests conducted on the corrugated fiberboard are provided in order to thoroughly document the materials used in the test program for potential future comparisons. [Table 3] [Table 4] [Figure 1]

A total of 21 CLSM mixtures was tested in the investigation (Table 5). Aggregate material quantities are reported for saturated surface dry conditions in the table. The mixtures were assigned designations for reference: the number preceding the letter $\mathrm{C}$ is the percentage 
of fine aggregate replaced by corrugate, and the number following the hyphen is the $\mathrm{c} / \mathrm{cm}$ ratio expressed as a percentage. For example, in mixture $0.5 \mathrm{C}-65,0.5 \%$ of the fine aggregate was replaced with corrugate, and $65 \%$ of the cementitious material was cement (the remaining $35 \%$ is fly ash). The water quantities provided in Table 5 represent all water in the mixture beyond the saturated surface dry condition of the fine aggregate. The amount of water that was held by the fiberized corrugate versus the amount that was available for the hydration of cement was not quantified. The amount that is held by the fiberized corrugate is variable as a function of confining stress conditions as the fibers represent a compressible solids fraction of the mixtures. [Table 5]

The first round of testing was conducted using batches with an approximate volume of $0.057 \mathrm{~m}^{3}\left(2.0 \mathrm{ft}^{3}\right)$, termed full-scale batches. The majority of tests were conducted using batches of approximately $0.014 \mathrm{~m}^{3}\left(0.5 \mathrm{ft}^{3}\right)$, termed small-scale batches. The actual volumetric batch sizes varied due to the effects of decreased specific gravity of the corrugate as compared to the fine aggregate.

Adjustments to the water content were made based on aggregate absorption and moisture content. Water masses equal to those of the baseline mixtures were used as a starting point for mixtures containing corrugate. Water was added as needed to reach equivalent flowability as compared to the baseline. The amount of added water was recorded to calculate the actual batched proportions (reported in Table 5). A similar approach was used previously by Cheung et al. [19] to prepare CLSM mixtures with shredded rubber tires used as a fine aggregate replacement.

Prior to the preparation of the test batches, individual materials were weighed and sealed in buckets in order to prevent changes in their moisture content. After the corrugate was 
fiberized, the pulp was allowed to drain in order to remove some of the excess water. The mass of the corrugate and the total pulp mass were recorded to determine the effective water content of the pulp. Some but not all of this water was assumed to be available as free water in the CLSM mixture.

Materials were mixed in a Multiquip rotary drum mixer (MC64PE) for full-scale batches and in a mortar mixer for small-scale batches. Materials were added in a manner consistent with the order provided by the ACI [1]. First, approximately half of the aggregate and approximately $75 \%$ of the mix water were added. After mixing for several revolutions the cementitious materials were added, followed by the remaining aggregate and the balance of the mixing water. For mixtures with corrugate, the water content of the pulp was close to, if not in excess of, the baseline water content. For these mixtures, the addition of the fiberized corrugate-water blend was adjusted so as to follow the procedure described by the ACI [1].

\section{Testing Procedures}

Fresh Batch Tests-The fresh batches were tested for flowability, bleeding, density, and air content. Flowability of the CLSM mixtures was determined according to ASTM D6103 [10]. This test was performed by filling a 75 diameter x 150 height cylindrical mold with CLSM and then lifting the cylinder vertically, allowing the material to flow out the bottom of the mold. The diametral spread of the mixture was measured across two perpendicular axes, and the average was recorded. For this test program, a flow consistency of $200 \mathrm{~mm}$ was

established as the minimum threshold for acceptance [1]. An additional criterion used to assess flowability relates to the lack of excessive bleed water and segregation in a test material. In cases in which excessive bleed water was observed, no additional water was used, and the cylinders were cast for strength testing. 
Bleeding was qualitatively assessed based on the procedure reported by Cheung [37]. Bleeding was considered excessive if substantial bleed water was observed immediately after placement. Severe bleeding refers to substantial bleed water in the 20 min following placement. Moderate or minor bleeding referred to less pronounced bleeding that was not likely to detrimentally affect the properties of the CLSM.

The density of each test batch was determined according to ASTM D6023 [38]. The mold used for density measurements had a volume of $7079 \mathrm{~cm}^{3}\left(0.25 \mathrm{ft}^{3}\right)$. The air content was determined using a pressure meter according to ASTM C231 [39]. This method was selected because the air content could not be calculated using the amount of materials included in a given mixture, due to the uncertainty in the amount of water absorbed by the corrugate.

Strength Tests-After the materials were mixed and fresh batch tests were conducted, 150 mm x $300 \mathrm{~mm}$ cylinders were prepared in accordance with ASTM D4832 [40]. Six specimens were prepared for each full-scale batch for replicate testing at 7, 14, and 28 days. For small-scale batches, two cylinders were prepared for testing at 28 days. Specimens were removed from the molds by cutting the molds. Unconfined compressive strength tests could not be conducted on some weak specimens that were damaged during removal from the molds.

Subsequent to removal from the molds, specimens were capped with Hydrostone plaster to provide a smooth bearing surface. Plaster was selected as the capping material to avoid damaging weak specimens, which can occur with sulfur capping compounds. Compression tests were conducted in accordance with ASTM C39 [41] using a loading rate of $100 \mathrm{kPa} / \mathrm{s}$. 


\section{Results and Discussion}

The results of the test program are summarized in Table 6. In general, the addition of corrugate resulted in lower densities for the CLSM mixtures. This was attributed to the combined effect of the lower specific gravity of the corrugate as compared to fine aggregate and the increased entrapped air in the mixtures. Plots of density and air content versus corrugate content are presented in Figs. 2 and 3, respectively. The addition of corrugate resulted in the use of higher water contents than in baseline mixtures to maintain acceptable flowability (Fig. 4). The increased water demand was attributed to both the water absorption by the corrugate and the increased shear resistance of the interlocking network of fibers. The normalized yield (the quotient of the volumetric yield of mixtures with corrugate and the volumetric yield of baseline mixtures) versus corrugate content is presented in Fig. 5. The combined effect of the decreased specific gravity of the corrugate and air entrapment resulted in a bulking of the mixtures. Corrugate replacement ratios on the order of $4 \%$ by weight produce a $30 \%$ bulking (i.e., $30 \%$ increase in total volume).

The unconfined compressive strength of CLSM mixtures was significantly affected by the presence of corrugate. At medium replacement rates (1 \% by $r$ weight), the resulting 28-day strengths were between $17 \%$ and $31 \%$ of the strengths of the baseline mixtures. A higher reduction in strength was observed for the all-cement mixtures $(\mathrm{c} / \mathrm{cm}=1)$ as compared to the mixtures that contained fly ash. The presence of organics in corrugate was assumed to detrimentally affect the strength gain of the cement [8]. The overall reduction in strength with the addition of corrugate also was attributed to the increased water/cement ratio of the mixtures containing corrugate. A design chart for selecting corrugate replacement quantities for CLSM mixtures is presented in Fig. 6. [Table 6] [Figure 2] [Figure 3] 
The fibers of the corrugate in the mixture are of sufficiently consistent geometry to provide discrete reinforcement throughout the matrix; however, the strength of the individual fibers is virtually negligible in this regard. The detrimental effects on strength heavily outweigh any benefit from the reinforcement mechanism. The durability of CLSM that incorporates fiberized corrugate remains a potential concern that was not evaluated in the current study. Further testing is required in this regard. Testing by Naik et al. [42] on concrete slabs containing paper-mill fibrous residuals indicated that the presence of fibrous residuals enhanced the freeze-thaw durability of non-air-entrained concrete. [Figure 4] [Figure 5]

An economic analysis was conducted to further evaluate the feasibility of incorporating corrugate in CLSM. The cost of mixtures was determined using typical costs for individual materials. The costs per metric ton of the materials were: cement (\$99/ton), fly ash $(\$ 83 /$ ton), fine aggregate $(\$ 22 /$ ton), water $(\$ 0.80 /$ ton), and pulped corrugate (\$200/ton). A plot of the resulting cost per mixture versus corrugate content is presented in Fig. 7. Due to the volumetric bulking, the addition of corrugate significantly reduced the calculated costs of the mixtures, even though the unit price of pulped corrugate is higher than the unit price of fine aggregate. [Figure 6] [Figure 7]

An analysis that combines strength characteristics with cost of the mixtures is presented in Figs. 8 and 9. Both plots present compressive strength versus cost. Figure 8 presents this relationship as a function of the $\mathrm{c} / \mathrm{cm}$ ratio, and Fig. 9 presents the relationship as a function of the corrugate content. In terms of cost, the all-cement mixtures $(\mathrm{c} / \mathrm{cm}=1)$ provide the highest strength for a given cost (or the least cost for a given strength). The dashed lines in Fig. 9 represent the typical range of strengths for excavatable CLSM. Based on Fig. 9, the economic 
benefits of aggregate replacement with corrugate are evident for several mixtures with strengths associated with excavatable CLSM. Specifically, mixtures with costs less than $\$ 50 / \mathrm{m}^{3}$ are economically attractive, with material cost savings of approximately 7 to $13 \%$ (for mixtures with $\mathrm{c} / \mathrm{cm}=0.65)$ for corrugate replacement ratios up to $1 \%$ in comparison to baseline mixtures with no corrugate.[Figure 8] [Figure 9]

\section{Conclusions}

This investigation was conducted to determine the feasibility of using corrugated fiberboard in CLSM applications. Corrugate was used as a fine aggregate replacement in the preparation of CLSM mixtures. Based on the results of the experimental test program, the following conclusions were drawn:

- As the corrugate content increased, the air content and water demand increased, the density and compressive strength decreased, and some mixtures were observed to exhibit excessive bleeding.

- The differences in engineering properties between the baseline mixtures and mixtures with corrugate were attributed to corrugate characteristics including low specific gravity, high water absorption capacity, and high organics content, as well as the presence of a fibrous matrix that influenced entrapped air and flow characteristics.

- Corrugate may be used to replace up to 1 to $2 \%$ of fine aggregate while maintaining appropriate engineering properties for excavatable CLSM. Selected mixtures with replacement ratios of up to $1 \%$ were economically beneficial, with approximately 7 to $13 \%$ material cost savings. 
- Overall, CLSM applications provide a new and potentially viable beneficial reuse alternative for paper/paperboard products, which constitute a significant fraction of the municipal solid waste stream in the United States.

\section{Acknowledgments}

This study was supported by the Office of Naval Research (Award No. N0001408-10855) and by the Global Waste Research Institute at California Polytechnic State University

\section{References}

[1] ACI Committee 229, "Controlled Low-Strength Materials," ACI 229-99(05), American Concrete Institute, Farmington Hills, MI, 2010.

[2] ACI Committee 116, "Cement and Concrete Terminology," ACI 116R-00, American Concrete Institute, Farmington Hills, MI, 2010.

[3] ASTM C150/C150M-09, 2010, "Standard Specification for Portland Cement," ASTM International, West Conshohocken, PA, www.astm.org.

[4] ASTM C595/C595M-10, 2010, "Standard Specification for Blended Hydraulic Cements," ASTM International, West Conshohocken, PA, www.astm.org.

[5] ASTM C618-08a, 2010, "Standard Specification for Coal Fly Ash and Raw or Calcined Natural Pozzolan for Use in Concrete," ASTM International, West Conshohocken, PA, wWw.astm.org.

[6] Turkel, S., "Long-Term Compressive Strength and Some Other Properties of Controlled Low Strength Materials Made with Pozzolanic Cement and Class C Fly Ash," J. Hazard. Mater., Vol. B137, 2006, pp. 261-266. 
[7] ASTM C33/C33M-08, 2010, "Standard Specification for Concrete Aggregates," ASTM International, West Conshohocken, PA, www.astm.org.

[8] Kosmatka, S. H., Kerkhoff, B., and Panarese, W. C., Design and Control of Concrete Mixtures, 14th ed., Portland Cement Association, Chicago, IL, 2008, p. 358.

[9] ASTM C1602/C1602M-06, 2010, "Standard Specification for Mixing Water Used in the Production of Hydraulic Cement Concrete," ASTM International, West Conshohocken, PA, www.astm.org.

[10] ASTM D6103-04, 2010, "Standard Test Method for Flow Consistency of Controlled Low Strength Material (CLSM)," ASTM International, West Conshohocken, PA, www.astm.org.

[11] Riggs, E. H., and Keck, R. H., "Specifications and Use of Controlled Low-Strength Material by State Transportation Agencies," The Design and Application of Controlled Low-Strength Materials (Flowable Fill), ASTM STP 1331, A. Howard and J. Hitch, Eds., ASTM International, West Conshohocken, PA, 1998, pp. 296-305.

[12] Naik, T. R., Ramme, B. W., and Kolbeck, H. J., "Filing Abandoned Underground Facilities with CLSM Fly Ash Slurry," Concr. Int., Vol. 12(7), 1990, pp. 19-25.

[13] Deng, A., and Tikalsky, P. J., "Geotechnical and Leaching Properties of Flowable Fill Incorporating Waste Foundry Sand," Waste Manage., Vol. 28, 2008, pp. 2161-2170.

[14] Naik, T. R., and Singh, S. S., "Flowable Slurry Containing Foundry Sands," J. Mater. Civ. Eng., Vol. 9, 1997, pp. 93-102.

[15] Tikalsky, P. J., Smith, E., and Regan, R. W., "Proportioning Spent Casting Sand in Controlled Low Strength Materials," ACI Mater. J., Vol. 95(6), 1998, pp. 740-746. 
[16] Wang, H.-Y., "A Study of the Engineering Properties of Waste LCD Glass Applied to Controlled Low Strength Materials Concrete," Constr. Build. Mater., Vol. 23, 2009, pp. 2127-2131.

$578 \mathrm{JAI}$ • STP 1540 ON TESTING AND SPECIFICATION OF RECYCLED MATERIALS

[17] Sagoe-Crentsil, K. K., Brown, T., and Taylor, A. H., "Performance of Concrete Made with Commercially Produced Coarse Recycled Concrete Aggregate," Cem. Concr. Res., Vol. 31, 2001, pp. 707-712.

[18] Pierce, C. E., and Blackwell, M. C., "A Lightweight Flowable Fill Using Granulated Rubber Tires," J. Solid Waste Technol. Manage., Vol. 29(1), 2003, pp. 31-41.

[19] Cheung, T., Jansen, D. C., and Hanson, J. L., "Engineering Controlled Low Strength Materials Using Scrap Tire Rubber," Proceedings of Selected Sessions of GeoCongress 08: Characterization, Monitoring, and Modeling of GeoSystems, ASCE GSP No. 179, A. Alshawabkeh, K. R. Reddy, and M. V. Khire, Eds., ASCE, Reston, VA, 2008, pp. 622-629.

[20] Won, J.-P., Lee, Y.-S., and Park, H.-G., "Durability Characteristics of Controlled LowStrength Materials Containing Recycled Bottom Ash," Mag. Concrete Res., Vol. 64, 2004, pp. 429-436.

[21] Chun, Y.-M., Naik, T. R., and Kraus, R. N., "Pulp and Paper Mill Fibrous Residuals in Excavatable Flowable Fill," Proceedings of the International Conference: Sustainable Construction Materials and Technology, University of Wisconsin-Milwaukee CBU, 2007, pp. 44-50. 
[22] Horiguchi, T., Fujuta, R., and Shimura, K., "Applicability of Controlled Low Strength Materials with Incinerated Sewage Sludge Ash and Crushed Stone Powder," J. Mater. Civ. Eng., Vol. 23(6), 2011, pp. 767-771.

[23] U.S. Environmental Protection Agency, 2009, "Municipal Solid Waste Generation, Recycling, and Disposal in the United States: Detailed Tables and Figures for 2008,"http://www.epa.gov/epawaste/nonhaz/municipal/pubs/msw2008data.pdf (Last accessed 26 Aug 2010).

[24] Twede, D., and Selke, S., Cartons, Crates and Corrugated Board: Handbook of Paper and Wood Packaging Technology, DEStech Publications Inc., Lancaster, PA, 2005.

[25] Paper Industry Association Council, "2007 Recovered Paper Annual Statistics," http://stats.paperrecycles.org/ (Last accessed 6 May 2008).

[26] Yesiller, N., Stone, G. M., and Hanson, J. L., "Beneficial Reuse of Corrugated Board in Civil Engineering Applications," Proceedings of the Ninth Japanese Geotechnical Society National Symposium on Environmental Geotechnics , Japanese Geotechnical Society, Tokyo, 2011, pp. 379-384.

[27] ASTM C188-09, 2010, "Standard Test Method for Density of Hydraulic Cement," ASTM International, West Conshohocken, PA, www.astm.org.

[28] ASTM C128-07a, 2010, "Standard Test Method for Density, Relative Density (Specific Gravity), and Absorption of Fine Aggregate," ASTM International, West Conshohocken, PA, wWw.astm.org.

[29] ASTM C136-06, 2010, "Standard Test Method for Sieve Analysis of Fine and Coarse Aggregates," ASTM International, West Conshohocken, PA, www.astm.org. 
[30] International Safe Transit Association, "ISTA 2 Series Partial Simulation Performance Test Procedure," http://www.ista.org/fonns/AAoverview.pdf (Last accessed 26 Dec 2009).

[31] White, A., and Kendrick, J., "Recycling Paper Food Packaging with Corrugated Cardboard: A Proposal for a New Recyclability and Repulpability Protocol and Preliminary Test Results for Fiber-Based Hot Cups," Global Green USA's Coalition for Resource Recovery, New York, 2009.

[32] TAPPI T 410 om-02, 2003, "Grammage of Paper and Paperboard (Weight per Unit Area)," Technical Association of Pulp and Paper Industry, Norcross, GA.

[33] TAPPI T 810 om-06, 2006, "Bursting Strength of corrugated and Solid Fiberboard," Technical Association of Pulp and Paper Industry, Norcross, GA.

[34] TAPPI T 839 om-02, 2002, "Edgewise Compressive Strength of Corrugated Fiberboard Using the Clamp Method (Short Column Test)," Technical Association of Pulp and Paper Industry, Norcross, GA.

[35] TAPPI T 441 om-04, 2004, "Water Absorptiveness of Sized (Non-Bibulous) Paper, Paperboard, and Corrugated Fiberboard (Cobb Test)," Technical Association of Pulp and Paper Industry, Norcross, GA.

[35] ACI Committee 211, "Standard Practice for Selecting Proportions for Normal, Heavyweight and Mass Concrete," ACI 211.1-91(09), American Concrete Institute, Farmington Hills, MI, 2010.

[36] Cheung, T., 2007, "The Use of Scrap Tire Rubber Buffings in Flowable Fill," ${ }^{\circ}$ M.S. thesis, California Polytechnic State University. 
[37] ASTM D6023-07, 2010, "Standard Test Method for Density (Unit Weight), Yield, Cement Content, and Air Content (Gravimetric) of Controlled Low-Strength Material (CLSM)," ASTM International, West Conshohocken, PA, www.astm.org.

[38] ASTM C23I/C231M-10, 2010, "Standard Test Method for Air Content of Freshly Mixed Concrete by the Pressure Method," ASTM International, West Conshohocken, PA, www.astm.org.

[39] ASTM D4832-10, 2010, "Standard Test Method for Preparation and Testing of Controlled Low Strength Material (CLSM) Test Cylinders," ASTM International, West Conshohocken, PA, www.astm.org.

[40] ASTM C39/C39M-I0, 2010, "Standard Test Method for Compressive Strength of Cylindrical Concrete Specimens," ASTM International, West Conshohocken, PA, www.astm.org.

[41] Naik, T. R., Chun, Y.-M., and Kraus, N., "Durability of Concrete Slab Containing PaperMill Fibrous Residuals," Report No. CBU-2005-22, REP-593, Center for By-Products Utilization, University of Wisconsin, Milwaukee, 2006. 


\begin{tabular}{ll}
\hline Portland cement & Typically type I or II portland cement conforming to ASTM C150 \\
[3] is used for CLSM. Other cements, such as blended cements con- \\
forming to ASTM C595 [4], can be used if verified with successful \\
test results. \\
For use in CLSM, fly ash does not need to conform to either Class F \\
or Class C designation as defined in ASTM C618 [5]. This allows for \\
the use of substandard products such as ponded ash or basin ash \\
that are generally stockpiled or discarded [1]. These products gen- \\
erally have a high carbon content, making them undesirable for \\
use in conventional concrete mixtures. Fly ashes with carbon con- \\
tents of up to 22\% have been successfully used in CLSM mixtures \\
[1]. Due to its high calcium oxide content, Class C fly ash exhibits \\
some self-cementation reaction, resulting in long-term strength \\
gain. Such strength gain may render Class C fly ash unacceptable \\
for use in CLSM, resulting in mixtures with compressive strengths \\
greater than 2.1 MPa when re-excavation is likely to occur [6]. \\
The aggregate types used in the production of CLSM vary widely. \\
Mixtures may contain fine aggregate, coarse aggregate, a combina- \\
tion of both, or no aggregate at all. Aggregates used in CLSM gener- \\
ally conform to the requirements of ASTM C33 [7] because ready \\
mix suppliers have these materials on hand. However, aggregates \\
not meeting the requirements in ASTM C33, normally used in con- - \\
crete production, may be used as an alternative [1]. \\
Generally, any potable water is suitable for use in concrete mix- \\
tures [8], although non-potable water can also be used. Additional \\
requirements for water are provided in ASTM C1602 [9]. \\
Aggregates
\end{tabular}

TABLE 1-Materials in conventional CLSM.

\begin{tabular}{lcc}
\hline Material Used & Replacement Rate & Reference(s) \\
\hline Spent foundry sand & 30 to $100 \%$ & $13-15$ \\
Recycled glass & 10 to $30 \%$ & 16 \\
Recycled concrete & $100 \%$ & 17 \\
Scrap tire rubber & 15 to $50 \%$ & 18,19 \\
Coal combustion products & 5 to $31 \%$ & $1,12,201) 11$ ) \\
Pulp and paper mill residuals & 2 to $20 \%$ & 21 \\
Incinerated sewage sludge ash & 10 to $30 \%$ & 22 \\
\hline
\end{tabular}

TABLE 2-Summary of byproduct materials in CLSM. 


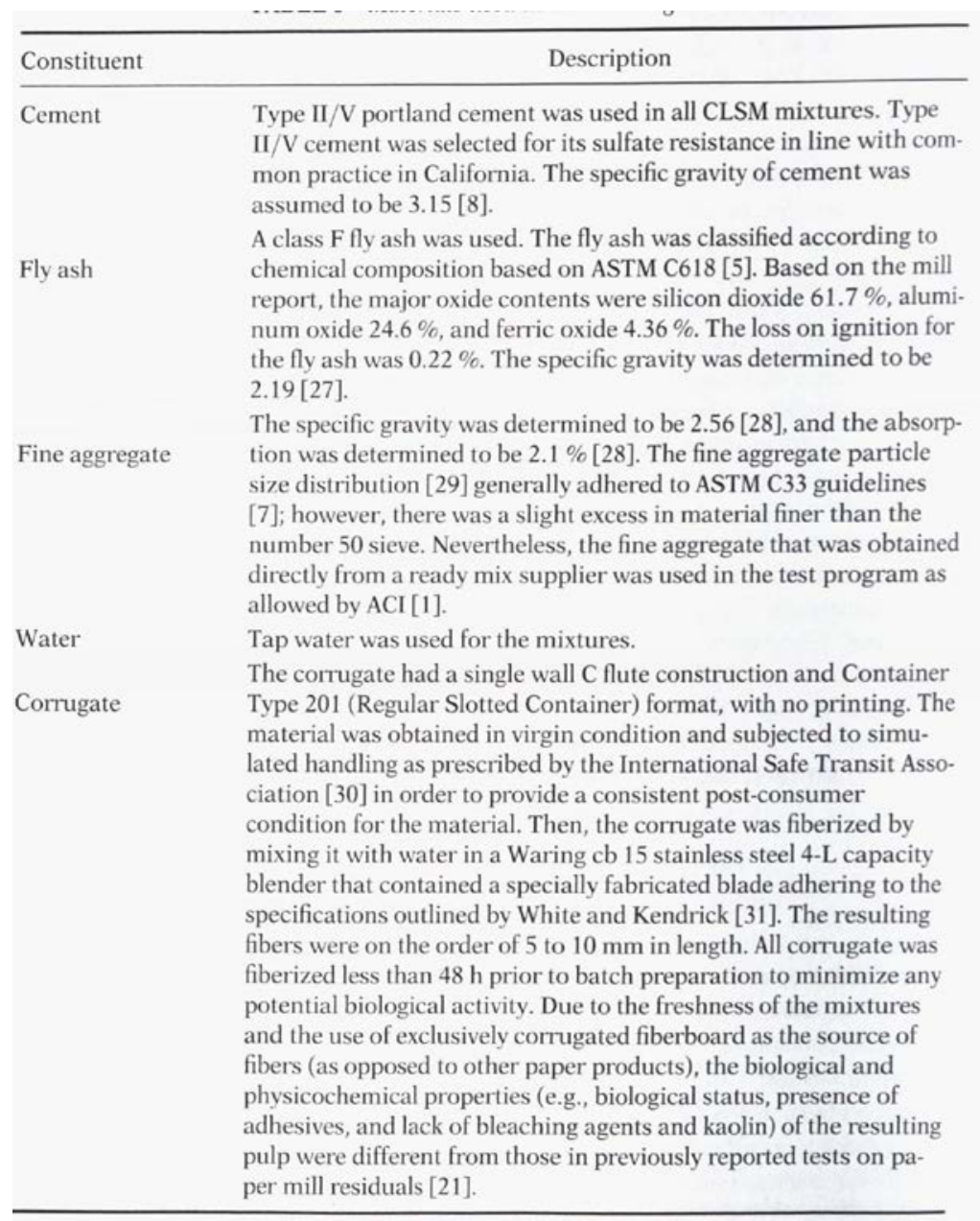

TABLE 3-Materials used in this investigation.

\begin{tabular}{|c|c|c|c|}
\hline Test & Standard Designation & Description of Test & Average Value \\
\hline $\begin{array}{l}\text { Grammage of paper and paperboard (weight } \\
\text { per unit area) }\end{array}$ & TAPPI T 410 om-02 [32] & $\begin{array}{l}\text { Weight per } 92.90 \mathrm{~m}^{2} \text { of all three container- } \\
\text { board components of a single wall corrugated } \\
\text { fiberboard is determined after conditioning } \\
\text { for } 24 \text { h at } 21 \pm 1 \mathrm{C} \text { temperature and } 52 \pm 0.5 \\
\% \text { relative humidity. }\end{array}$ & $588 \mathrm{~g} / \mathrm{m}^{2}$ \\
\hline $\begin{array}{l}\text { Bursting strength of corrugated and solid } \\
\text { fiberboard }\end{array}$ & TAPPI T 810 om-06 [33] & $\begin{array}{l}\text { Square corrugated fiberboard specimens with } \\
\text { dimensions of } 31.50 \pm 0.03 \mathrm{~mm} \text { are tested by } \\
\text { distending an expandable diaphragm under a } \\
\text { pressure of } 690 \mathrm{kPa} \text { to } 4825 \mathrm{kPa} \text {. }\end{array}$ & $1140 \mathrm{kPa}$ \\
\hline $\begin{array}{l}\text { Edgewise compressive strength of corrugated } \\
\text { fiberboard }\end{array}$ & TAPPI T 839 om-02 [34] & $\begin{array}{l}\text { A test specimen with length } 50.8 \pm 0.8 \mathrm{~mm} \\
\text { and height } 25.4 \pm 0.4 \mathrm{~mm} \text { is compressed verti- } \\
\text { cally (load parallel to flutes) to failure at the } \\
\text { rate of } 111 \pm 22 \mathrm{~N} / \mathrm{s} \text {. }\end{array}$ & $146 \mathrm{~N}$ \\
\hline $\begin{array}{l}\text { Water absorptiveness of corrugated fiber- } \\
\text { board (Cobb test) }\end{array}$ & TAPPI T 441 om-04 [35] & $\begin{array}{l}\text { A test specimen with a diameter of } \\
11.28 \pm 0.02 \mathrm{~cm} \text { is exposed to } 100 \mathrm{ml} \text { of water } \\
\left(23 \pm 1^{\circ} \mathrm{C}\right) \text { and a head of } \mathrm{l} \pm 0.1 \mathrm{~cm} \text { for } 120 \mathrm{~s} \text {. }\end{array}$ & $89.0 \mathrm{~g} / \mathrm{m}^{2}$ \\
\hline
\end{tabular}

TABLE 4-Corrugated fiberboard properties. 


\begin{tabular}{|c|c|c|c|c|c|c|c|c|}
\hline $\begin{array}{l}\text { Mixture } \\
\text { Designation }\end{array}$ & $\begin{array}{l}\text { Batch } \\
\text { Size }\end{array}$ & $\begin{array}{l}\text { Cement, } \\
\mathrm{kg} / \mathrm{m}^{3}\end{array}$ & $\begin{array}{l}\text { Fly Ash, } \\
\mathrm{kg} / \mathrm{m}^{3}\end{array}$ & $\begin{array}{l}\text { Fine Aggregate, } \\
\qquad \mathrm{kg} / \mathrm{m}^{3}\end{array}$ & $\begin{array}{l}\text { Water, } \\
\mathrm{kg} / \mathrm{m}^{3}\end{array}$ & $\begin{array}{c}\text { Corrugate, } \\
\mathrm{kg} / \mathrm{m}^{3}\end{array}$ & $\begin{array}{l}\text { Water/Cementitious } \\
\text { Materials, } \mathrm{kg} / \mathrm{kg}\end{array}$ & $\begin{array}{c}\text { Corrugate } \\
\text { Solids, } \mathrm{m}^{3} / \mathrm{m}^{3}\end{array}$ \\
\hline $0 \mathrm{C}-100$ & Small & 206.4 & 0.0 & 1553.0 & 295.3 & 0.0 & 1.4 & 0.000 \\
\hline $0.25 C-100$ & Small & 209.4 & 0.0 & 1554.7 & 223.2 & 3.9 & 1.1 & 0.003 \\
\hline $0.5 \mathrm{C}-100$ & Small & 176.2 & 0.0 & 1306.8 & 375.9 & 6.5 & 2.1 & 0.005 \\
\hline $1.0 \mathrm{C}-100$ & Small & 154.4 & 0.0 & 1140.8 & 431.8 & 11.4 & 2.8 & 0.009 \\
\hline $2.0 \mathrm{C}-100$ & Small & 132.6 & 0.0 & 969.3 & 528.2 & 19.6 & 4.0 & 0.015 \\
\hline $4.0 C-100$ & Small & 98.6 & 0.0 & 717.1 & 567.6 & 28.8 & 5.8 & 0.023 \\
\hline $6.0 C-100$ & Small & 67.2 & 0.0 & 485.2 & 719.7 & 29.7 & 10.7 & 0.022 \\
\hline $0.0 C-65$ & Small & 135.2 & 74.0 & 1535.6 & 311.9 & 0.0 & 1.5 & 0.000 \\
\hline $0.25 C-65$ & Small & 115.9 & 63.5 & 1328.7 & 193.6 & 3.3 & 1.1 & 0.003 \\
\hline $0.5 C-65$ & Small & 124.0 & 67.9 & 1394.2 & 271.0 & 7.1 & 1.4 & 0.006 \\
\hline $1.0 \mathrm{C}-65$ & Small & 115.7 & 63.3 & 1287.7 & 302.0 & 13.2 & 1.7 & 0.011 \\
\hline $2.0 \mathrm{C}-65$ & Small & 82.9 & 45.4 & 922.2 & 550.3 & 19.4 & 4.3 & 0.014 \\
\hline $4.0 C-65$ & Small & 67.0 & 36.7 & 730.7 & 701.5 & 30.3 & 6.8 & 0.021 \\
\hline $6.0 \mathrm{C}-65$ & Small & 50.9 & 27.3 & 546.6 & 812.0 & 34.5 & 10.4 & 0.023 \\
\hline $0 C-29$ & Full & 58.3 & 145.1 & 1472.6 & 290.8 & 0.0 & 1.4 & 0.000 \\
\hline $0.25 C-29$ & Small & 64.3 & 155.6 & 1628.2 & 152.0 & 4.1 & 0.7 & 0.003 \\
\hline $0.5 C-29$ & Small & 61.0 & 147.6 & 1489.4 & 225.3 & 7.7 & 1.1 & 0.006 \\
\hline $1.0 C-29$ & Small & 51.8 & 125.4 & 1252.3 & 348.4 & 13.1 & 2.0 & 0.010 \\
\hline $2.0 C-29$ & Full & 44.7 & 111.2 & 1106.2 & 267.1 & 22.3 & 1.7 & 0.021 \\
\hline $4.0 C-29$ & Full & 35.5 & 88.3 & 860.6 & 282.7 & 36.0 & 2.3 & 0.037 \\
\hline $6.0 C-29$ & Full & 38.0 & 95.2 & 907.5 & 341.3 & 57.8 & 2.6 & 0.053 \\
\hline
\end{tabular}

TABLE 5-Summary of CLSM mixtures.

\begin{tabular}{lcccc}
\hline $\begin{array}{l}\text { Mix } \\
\text { Designation }\end{array}$ & $\begin{array}{c}\text { Flow, } \\
\mathrm{mm}\end{array}$ & $\begin{array}{c}\text { Density, } \\
\mathrm{kg} / \mathrm{m}^{3}\end{array}$ & $\begin{array}{c}\text { Air Content, } \\
\%\end{array}$ & $\begin{array}{c}\text { 28-Day Compressive } \\
\text { Strength, MPa }\end{array}$ \\
\hline 0C-100 & 255 & 2057 & 2.7 & 3.9 \\
$0.25 \mathrm{C}-100$ & 205 & 1988 & 5.6 & 2.4 \\
$0.50 \mathrm{C}-100$ & 210 & 1862 & 6.0 & 1.2 \\
$1.0 \mathrm{C}-100$ & 210 & 1735 & 8.0 & 0.7 \\
$2.0 \mathrm{C}-100$ & 205 & 1647 & 7.0 & 0.3 \\
$4.0 \mathrm{C}-100$ & $180^{\mathrm{a}}$ & 1410 & 6.0 & 0.1 \\
$6.0 \mathrm{C}-100$ & $180^{\mathrm{a}}$ & 1300 & 5.0 & 0.0 \\
$0 \mathrm{C}-65$ & 265 & 2053 & 1.3 & 1.1 \\
$0.25 \mathrm{C}-65$ & 235 & 1702 & 5.6 & 1.1 \\
$0.50 \mathrm{C}-65$ & 230 & 1861 & 3.4 & 0.7 \\
$1.0 \mathrm{C}-65$ & 210 & 1779 & 6.0 & 0.3 \\
$2.0 \mathrm{C}-65$ & 220 & 1617 & 7.0 & 0.2 \\
$4.0 \mathrm{C}-65$ & 210 & 1564 & 7.0 & 0.0 \\
$6.0 \mathrm{C}-65$ & 205 & 1468 & 8.5 & 0.0 \\
$0 \mathrm{C}-29$ & 330 & 1964 & 0.7 & 0.7 \\
$0.25 \mathrm{C}-29$ & 255 & 2001 & 5.0 & 0.4 \\
$0.50 \mathrm{C}-29$ & 260 & 1928 & 4.3 & 0.3 \\
$1.0 \mathrm{C}-29$ & 235 & 1788 & 4.3 & 0.2 \\
$2.0 \mathrm{C}-29$ & 220 & 1549 & 9.4 & 0.2 \\
$4.0 \mathrm{C}-29$ & $\mathrm{~N} / \mathrm{A}^{\mathrm{a}}$ & 1301 & 21.0 & 0.1 \\
$6.0 \mathrm{C}-29$ & $\mathrm{~N} / \mathrm{A}^{\mathrm{a}}$ & 1437 & 5.0 & $\mathrm{~N} / \mathrm{A}$ \\
\hline
\end{tabular}

${ }^{a}$ Mixture did not meet flow requirements due to excessive bleeding.

TABLE 6-Test results. 

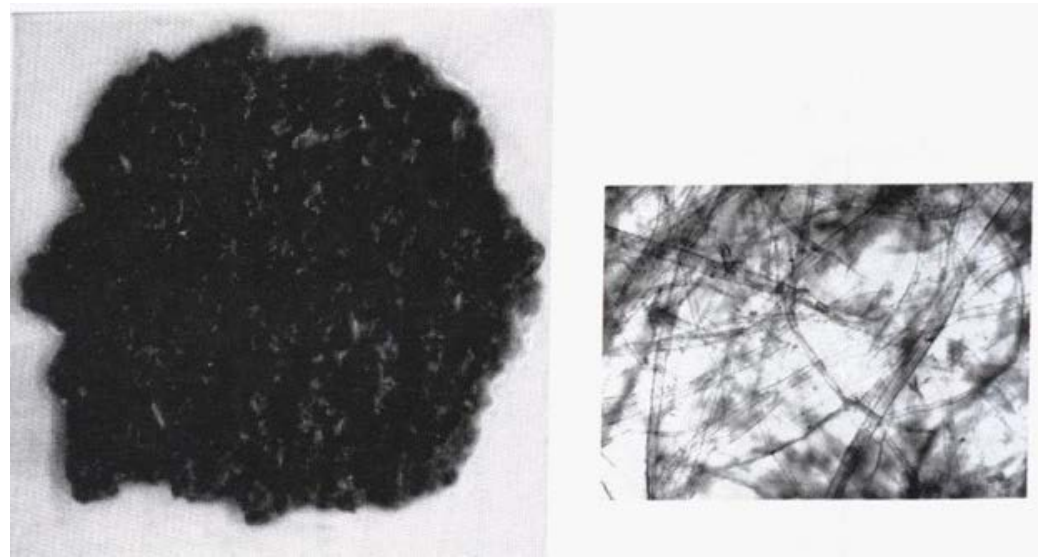

FIG. 1-Sample of fiberized (i.e., pulped) corrugated board and microscopic image of fibers.

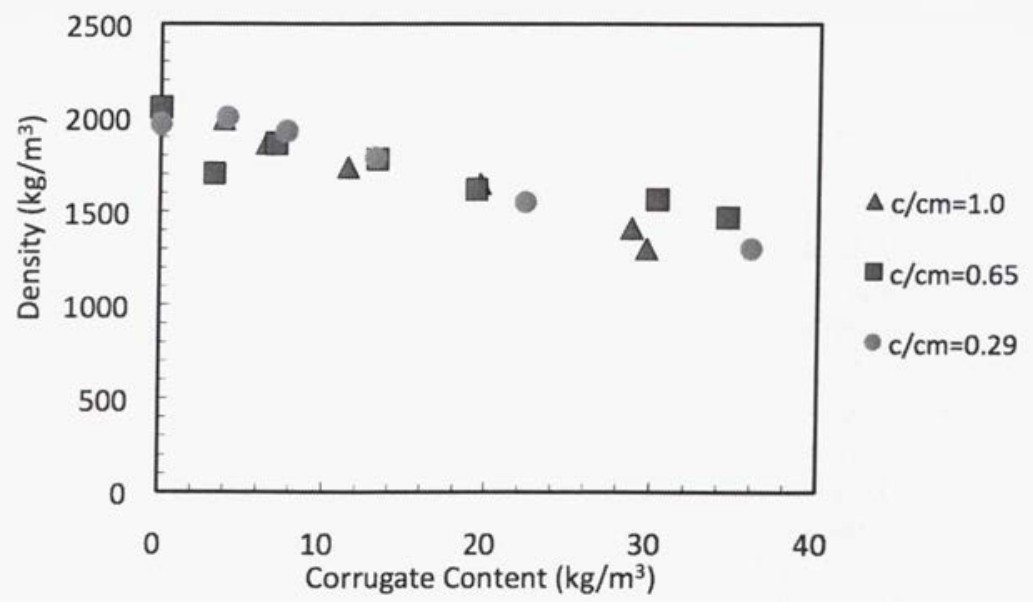

FIG. 2-Density versus corrugate content. 


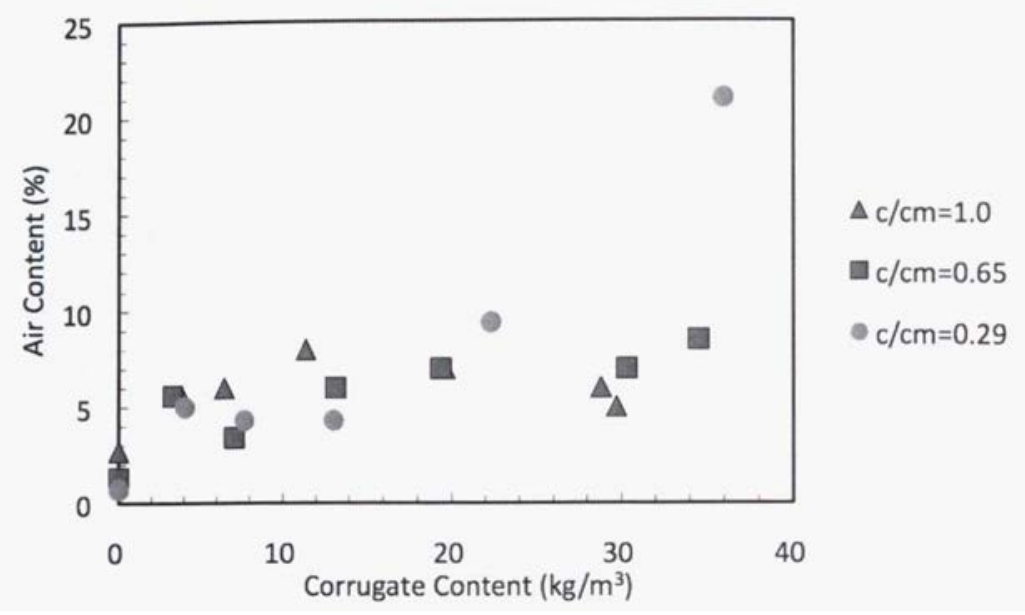

FIG. 3-Air content versus corrugate content.

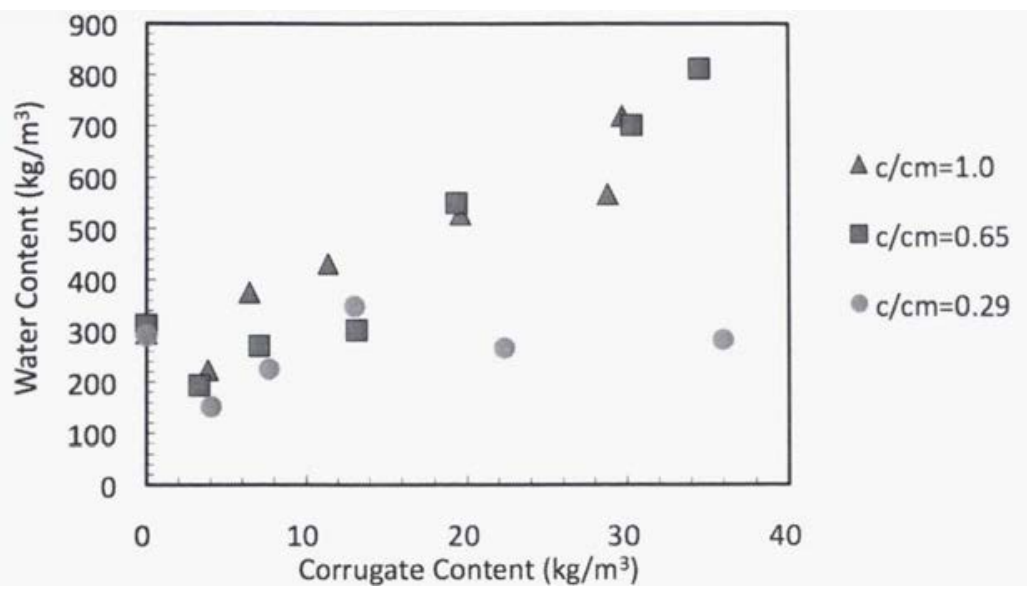

FIG. 4-Water demand versus corrugate content. 


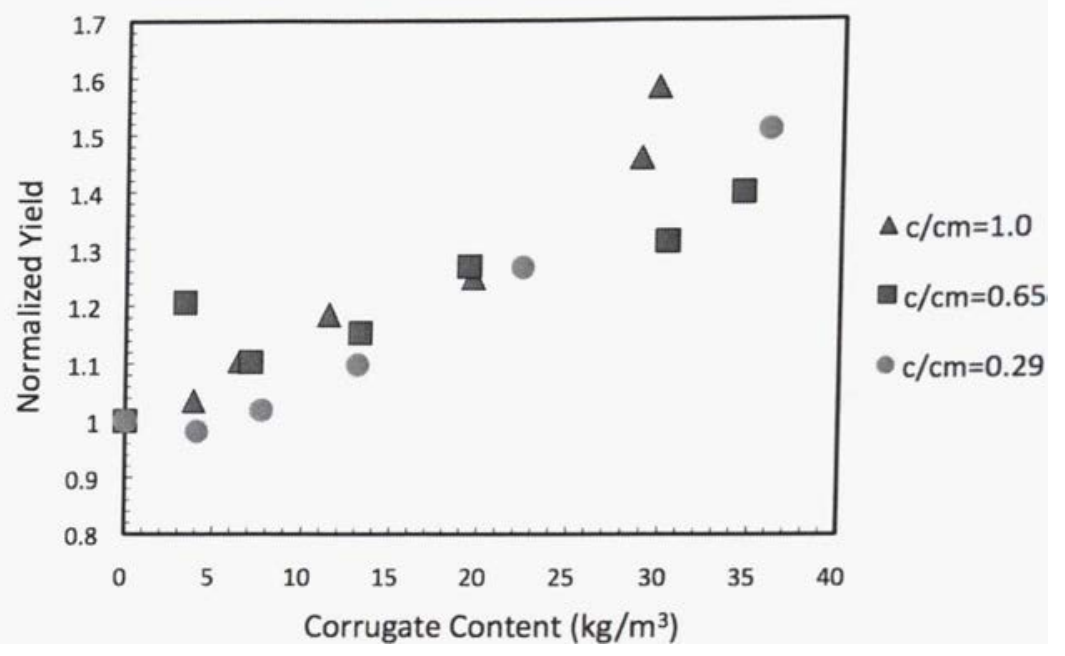

FIG. 5-Normalized yield versus corrugate content.

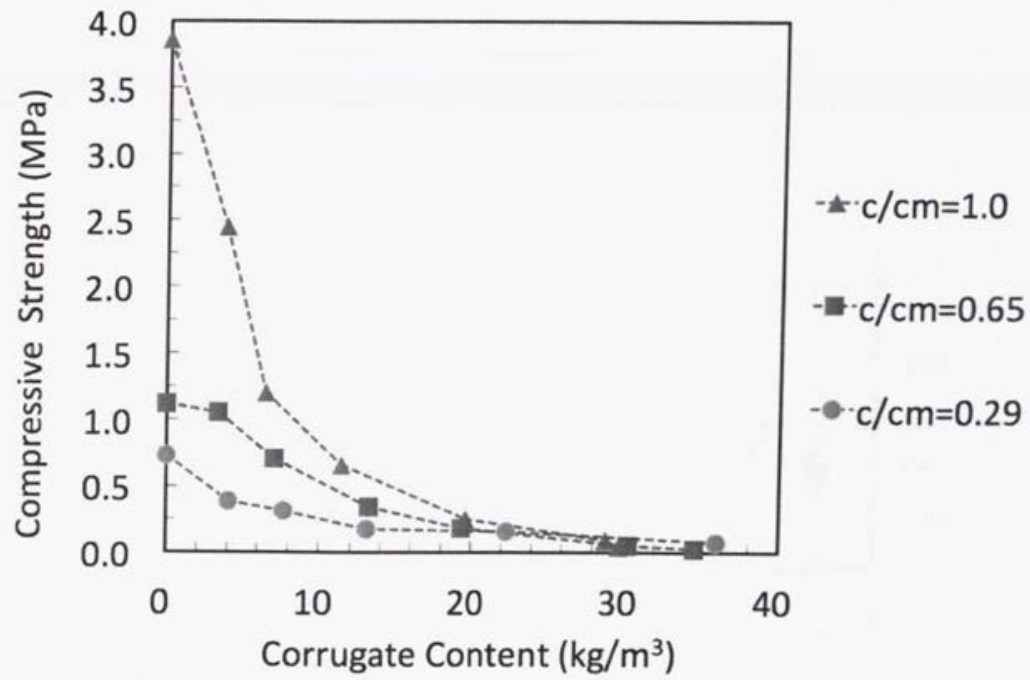

FIG. 6-Design chart for unconfined compressive strength versus corrugate content. 


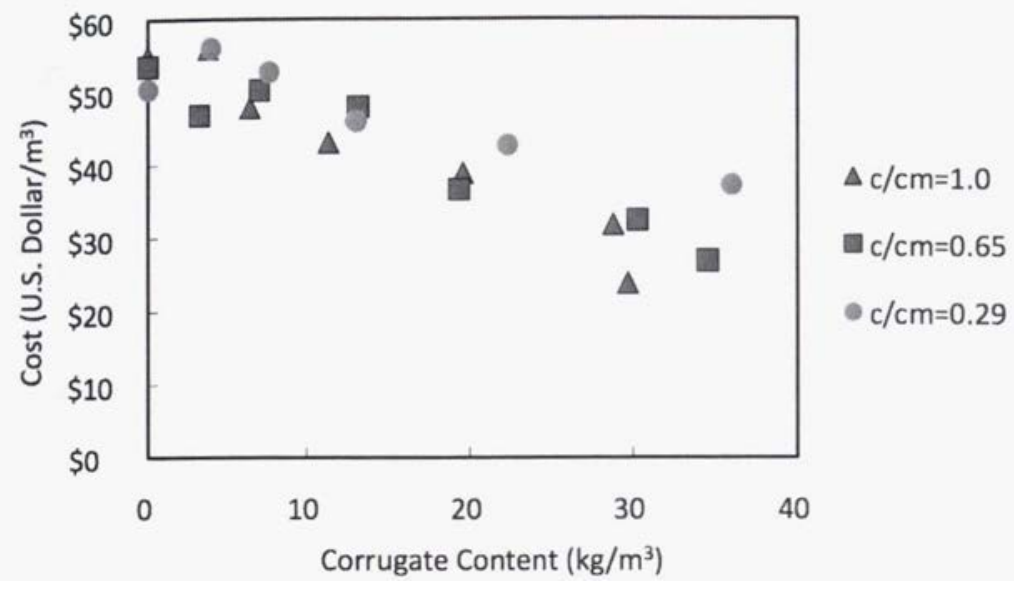

FIG. 7-Cost of mixtures versus corrugate content.

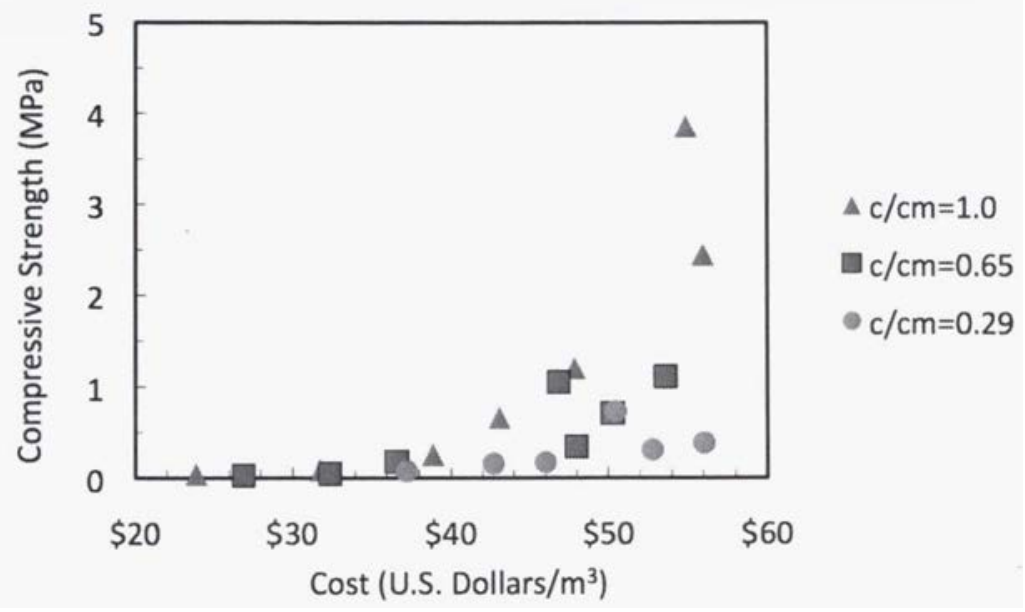

FIG. 8-Compressive strength versus cost for variable c/cm ratios. 


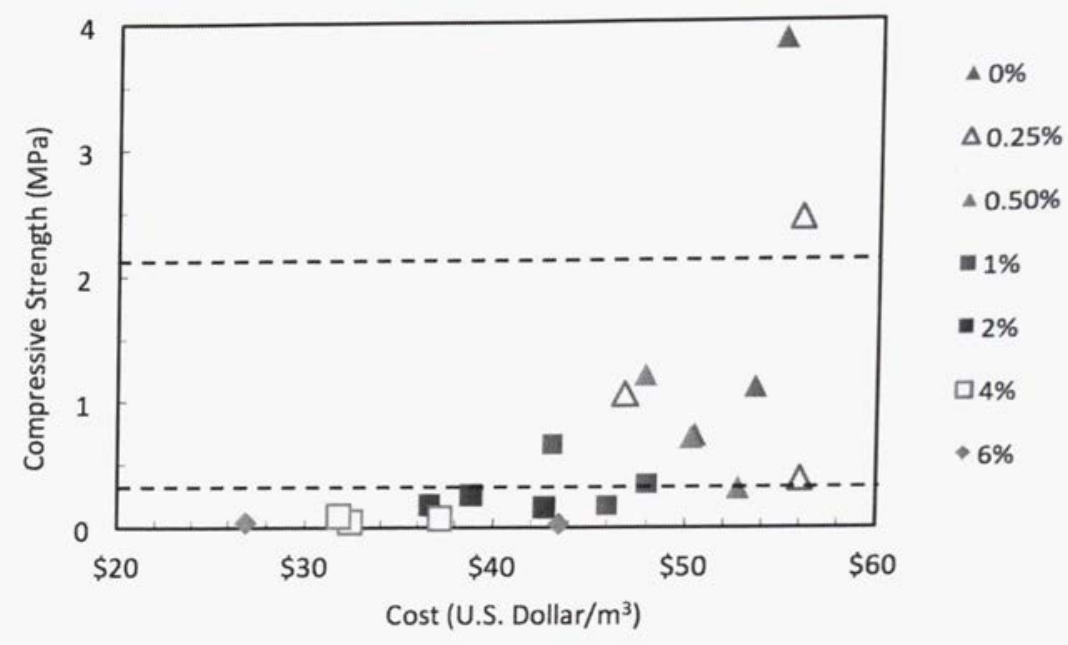

FIG. 9-Compressive strength versus cost for variable corrugate replacement rates. 